KempthoRNe, O. (1957): An Introduction to Genetic Statistics. John Willey and Sons Lt., New York: 101-146.

Kumarvelu, G., Stanley, J., Rai, V. and Sampson, B. (1995): Provenances of Eucalyptus camaldulensis Dehnh and E. tereticornis $\mathrm{Sm}$ suitable to south Indian conditions - results of an IUFRO trial. Annals of Forestry 3(2): 129-133.

LACAZE, J. F. (1970): Studies on the ecological adaptation of Eucalyptus. Operational report for 1970 on project No. 6 . Document, $4^{\text {th }}$ Session Committee on the Coordination of Mediterranean Forestry Problems, Ankara, No. FO: SCM/FR 70/2/10. FAO, Rome.

LACAZE, J. F. (1978): Eucalyptus camaldulensis, Project FAO no. 6. In: Documents FAO third world consultation on forest tree breeding Vol. 1: 393-409. CSIRO, Canberra.

MoReshet, S. (1981): Physiological activity, in a semi arid environment, of Eucalyptus camaldulensis Dehn. from two provenances. Australian Journal of Botany 29: 97-110.
MourA, V. P. G. (1986): Provenance variation of Eucalyptus camaldulensis Dehnh. in Brazil. Unpublished D. Phil. thesis, University of Oxford.

RAO, D.V. (1984): Provenance trial of Eucalyptus. Indian Forester 110: 28-34.

RATHINAM, M., Suerndran, C. and KondAS, S. (1982): Interrelationship of wood yield component in Eucalyptus tereticornis Sm. Indian Forester 108: 460-470.

SidDiqUi, K. M., KJAN, M., and AKHTAR, S. (1979): Results of 10 year old Eucalyptus camaldulensis Dehn. provenance study at Peshwar. Silvae Genetica 28: 24-26.

SNEDECOR, G. W. and Cochran, W. G. (1967): Statistical Methods. Oxford and IBH, New Delhi. 593 pp.

Subramanian, K. N., Mandal, A. K. and Nicodemus, A. (1995): Genetic variability and character association in Eucalyptus grandis. Annals of Forestry 3 (2): 134-137.

\title{
Seed Source Variation in Growth Performance and Oil Yield of Jatropha curcas Linn. in Central India
}

\author{
By H. S. GinWAL", P. S. Rawat ${ }^{1}$ and R. L. SRIVASTAVA ${ }^{2}$ \\ Division of Genetics and Tree Propagation, Forest Research Institute, P.O. I.P.E. Kaulagarh Road, \\ Dehradun 248195 (Uttaranchal) India \\ (Received 27 $7^{\text {th }}$ October 2004)
}

\begin{abstract}
Results of a seed source evaluation trial of Jatropha curcas Linn. laid out in 1996 at Jabalpur (M.P), a semi arid region of India are reported and discussed. Seeds collected from ten sources from central India representing the states Madhya Pradesh and Maharashtra viz. Gondia, Bichia, Balaghat, Niwas, Khandwa, Burhanpur, Nasik, Chindwara, Kundam and Jabalpur were evaluated for their growth performance from nursery stage ( 3 months) to field (two years). Variation in seed oil content of different sources were also studied and reported. Significant differences between the seed sources at age 27 months were observed for height, collar diameter, number of branches leaf area and field survival. Seeds collected from different sources also varied significantly in respect of seed and kernel weight and oil content in seed/kernel. The Chhindwara (M.P.) source performed the best and yielded a maximum oil of $39.12 \%$ from whole seed and $58.12 \%$ from kernel. The oil content ranged from 33.02 to $39.12 \%$ in whole seeds and 47.08 to $58.12 \%$ in kernel, across the seed sources. The performance of Kundam (M.P.), Jabalpur (M.P.), Bichia (M.P.), Niwas (M.P.) and Nasik (Maharashtra) sources were also found satisfactory for oil yield. Results indicate that genetic differences exist between the seed sources of J. curcas. The growth traits showed significant positive correlation with each other. Fair differences between phenotypic and genotypic coefficient of variability were observed. Heritability (broad sense) values

\footnotetext{
* Author for correspondence: (e-mail: ginwalhs@icfre.org; ginwalhs@rediffmail.com)

${ }^{1}$ Division of Forest Pathology, Forest Research Institute, P.O. New Forest, Dehradun 248006 (Uttaranchal) India

${ }^{2}$ Arid Forest Research Institute, Jodhpur (Rajasthan), India.
}

were fairly good with regard to leaf area, height and collar diameter in comparison to survival percent. The relative performance of these sources was fairly consistent throughout the observation period.

Key words: Jatropha curcas, variation, provenance, genetic improvement, productivity, heritability, oil, diesel.

\section{Introduction}

Jatropha cuurcas Linn. (tropical physic nut) belonging to family Euphorbiaceae is a native species of tropical America, cultivated throughout the tropics and is sub-spontaneous in Mauritius and Seychelles (BAKER, 1877). It is a very prominent and widely acclaimed species with vide variety of uses. It is a small tree or large shrub, which can reach height of up to $5 \mathrm{~m}$ and has high potential for greening and eco-rehabilitation of wastelands as well as for bio-aesthetic reasons (HELLER, 1996). In India, it is found in semi-wild conditions in the vicinity of villages and is one of the most promising drought tolerant perennial plant adapted to various kinds of soil conditions (SRIVASTAVA, 1999). The plant is widely distributed and fits easily into agricultural systems in the form of hedges, windbreak, anti erosion barrier or source of firewood (SRIVASTAVA, 1999).

In the recent years energy conservation and its production has acquired significant importance in the wake of the world energy crisis. A number of options for production of liquid fuel as an alternative source have been considered in many countries. Oil seed crops are potential renewable sources of fuels and in this category $J$. curcas has won over the interest of various developmental agencies. The J. curcas oil has been identified as an efficient substitute to be used as fuel for diesel 
engines (BHASABUtRA and SUTIPONPEIBUN, 1982a; BHASABUtRA and Sutiponpeibun, 1982b; Raina, 1985). The engine performance and fuel consumption with $J$. curcas oil has been compared favourably with normal diesel oil (TAKEDA, 1982 b and TAKEDA and Minoru, 1981; Bhasabutra and SutiponPeibun, $1982 \mathrm{a}$, b; JARAY, 1984; MARTIN and MAYEZIX, 1984; MuNCH and KEIFER, 1989). Hence utilization of J. curcas oil as a new source of oil for diesel engine has tremendous scope in contributing to growing needs of country for energy resources. However, many specific questions about its production, commercialization and genetic improvement work are still in infancy.

No work on genetic improvement aspects of this species has been taken up so far in India. Systematic provenance trials at different locations have not yet been carried out with J. curcas in India and to the necessary extent in the world. The material from the center of origin has not been sufficiently screened (HELLER, 1996). The genetic background of the J. curcas grown in Africa and Asia is unclear (HELLER, 1996). At the global level the information on genetic improvement of J. curcas is restricted to few publications. Among the few reports, Sukarin et al. (1987) did not observe any morphological differences between 42 clones originating from different locations in Thailand. HELLER (1996) reported a significant difference in the vegetative development among 13 provenances of J. curcas in multilocation field trials in two countries viz. Senegal and Cape Verde and a significant genotype-environment-interaction ( $\mathrm{G} x$ E) in Senegal.

Owing to its importance, the species has gained popularity and is being scaled up in different parts of India on large scale. Being a naturalized species with a wide range of distribution, $J$. curcas embraces a considerable scope of variation, which suggests a high potential of this genus in India. The screening of existing populations for growth and oil yield, could be utilized profitably for selection of best sources for afforestation and productions of oil. There is a good reason for developing $J$. curcas as a new energy crop as it does not compete with conventional food crops for land, water and manpower resources and also it has the ability to make a significant contribution to the nation's growing needs for energy though large scale cultivation with ease (SRIVASTAVA, 1999). In the present study a total of ten sources of J. curcas representing the promising Jatropha occurring belt of tropical dry deciduous forests in central India, were screened and evaluated under a semi-arid environment. The objective of this study was to understand the magnitude of genetic variation in oil yield, growth behaviour and adaptability in central India to identify the best seed sources to be utilized for reforestation and future genetic improvement work. Also to generate basic information for initiating the range wide provenance tests including provenances of wide geographical origin involving many countries.

\section{Material and Methods}

The experiment was conducted at Tropical Forest Research Institute, Jabalpur which falls between $23000^{\prime} 30^{\prime \prime}$ to $23^{\circ} 02^{\prime} \mathrm{N}$ latitude and $79^{\circ} 59^{\prime} 30^{\prime \prime}$ to $80^{\circ} 02^{\prime} \mathrm{E}$ longitude. The area enjoys semi-arid type of climate with mean annual rainfall $1350 \mathrm{~mm}$.

Seeds of J. curcas were collected through the field surveys, at least from 10 parent plants chosen randomly from each population, which were situated about $100 \mathrm{~m}$ apart from each other. Seeds from each plant (at least 10\%) were collected and labeled to maintain the identity of seed parent. A uniform pretreatment was given to the seeds prior to sowing by soaking them in warm water $\left(40^{\circ} \mathrm{C}\right)$ for two hours, allowed to cool and kept soaked for 24 hours. Seeds were sown directly in polythene
Table 1. - Seed source detail of J. curcas and their geographical locations.

\begin{tabular}{|c|c|c|c|c|c|c|}
\hline $\begin{array}{l}\text { Seed } \\
\text { source } \\
\text { code }\end{array}$ & Locality & \begin{tabular}{|l} 
Latitude \\
$\left({ }^{0} \mathrm{~N}\right)$
\end{tabular} & 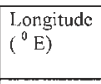 & \begin{tabular}{|l|} 
Altitude \\
( $m$ asl)
\end{tabular} & \begin{tabular}{|l}
$\begin{array}{l}\text { Rainfall } \\
(\mathrm{mm})\end{array}$ \\
\end{tabular} & $\begin{array}{l}\text { Mean temp } \\
{ }^{\circ} \mathrm{C} \\
(\text { min-max) }\end{array}$ \\
\hline si & Gondia (M.P.) & 20.38 & 79.50 & 550 & 1200 & $13.4-42.6$ \\
\hline s2 & Bichia (M.P) & 22.26 & 80.42 & 450 & 1490 & $8.7-43.0$ \\
\hline s3 & Niwas (M.P) & 23.20 & 79.57 & 70 & 1253 & $10.8-43.5$ \\
\hline \$4 & Balaghal (M.P) & 21.32 & 81.4 & 450 & 1365 & $8.2-43.2$ \\
\hline s5 & Khandwa (M.P.) & 22.10 & 75.56 & 500 & 1272 & $11,5-42,9$ \\
\hline s6 & Burhanpur (M.P.) & 21.20 & 76.11 & 250 & 1272 & $11.5-42.9$ \\
\hline s7 & Nasik (Mahrrashtra) & 19.35 & 73.23 & 513 & 714 & $8.7-36.4$ \\
\hline S8 & Chhindwara (M.P.) & 21.27 & 78.15 & 900 & 1063 & $4.2-41.6$ \\
\hline sq & Kundam (M.P.) & 23.12 & 80.21 & 380 & 1253 & $10.8-43.5$ \\
\hline $\begin{array}{l}\text { sio } \\
\text { (Local) }\end{array}$ & Jabalpur (M.P.) & 22,49 & 79.22 & 393 & 1263 & $11.0-43.5$ \\
\hline
\end{tabular}

bags (one seed per bag) containing potting mixture of sand, soil and farm yard manure in the ratio of 1:1:1 (by volume) in four replicates of 100 seeds each using randomized complete block design as per ISTA rules (1996). Prior to sowing, the polythene bags containing potting mixture were given fungicide treatment ( $0.2 \%$ Bavistin) and kept covered with plastic sheet for 24 hours. Daily germination observation was taken till the germination was completed. Seedlings were maintained in the nursery till their field planting. Four-month-old seedlings were planted in the field (pit size 45 x 45 x $45 \mathrm{~cm}$ ) in August 1996 in a randomized complete block design with three replications. Each source constituted a 25 tree square plot and the spacing from plant to plant was kept $3 \times 3 \mathrm{~m}$. All the 25 trees in each plot constituted the measuring unit. Observations were recorded on the trial periodically for plant height (m), collar diameter $(\mathrm{mm})$, number of branches and survival percentage. The first assessment was carried out 12 months after field planting and subsequently after 24 months. Leaf area was measured with a leaf area meter (LICOR-LI 3000) of 5 leaves chosen randomly from each tree and expressed as average leaf area per leaf. The leaf area was multiplied by the number of leaves occurring in the plant and was expressed as total leaf area per plant.

Extraction of seed oil was carried out following the method of ANON. (1965), in which the seed kernels were separated and powered. The oil was extracted from the powdered samples (known weight) in soxhlet extraction apparatus with petroleum ether $\left(60-80^{\circ} \mathrm{C}\right)$ for 6 hours without interruption by gently heating it. Ether was evaporated on a water bath until no odor of ether remained. The oil yield was expressed in term of percentage of powdered sample.

Data were subjected to analysis of variance and Least Significance Difference test using SPSS (version 6.1) computer program (SPSS Inc. 233 S. Wacker Drive, 11th floor, Chicago, IL 60606-6307). Linear correlation coefficients were calculated among the studied traits, as described by SNEDECOR and COCHRAN (1967). Genotypic and phenotypic coefficients of variation, heritability, genetic advance and genetic gain were calculated using the method of KEMPTHORNE (1957).

\section{Results}

The soil and site characteristics of J. curcas sources are given in Table 2. Soils of Chhindwara (S8) area are gravelly sandy loam. Soils in Niwas (S3) and Bichia (S2) are clay loam. However, Niwas (S3) is more gravelly. In Nasik (S7), Khandwa (S5) and Burhanpur (S6) soil texture is loam, sandy clay and clay loam respectively but dominantly gravelly. In areas of 
Table 2. - Site and soil characteristics of J. curcas sources.

\begin{tabular}{|c|c|c|c|c|c|c|c|}
\hline \multirow[t]{2}{*}{ Seed sources } & \multicolumn{7}{|c|}{ Site and soil characteristics } \\
\hline & $\begin{array}{l}\text { Geology/ } \\
\text { parent } \\
\text { material }\end{array}$ & Relief & $\begin{array}{l}\text { Slope } \\
(\%)\end{array}$ & Drainage & $\begin{array}{c}\text { Surface } \\
\text { stoniness }\end{array}$ & Texture & Soil depth \\
\hline Gondia (M.P.) & $\begin{array}{l}\text { Granite } \\
\text { gneiss }\end{array}$ & Plain & $1-3$ & $\begin{array}{c}\text { Moderately } \\
\text { well } \\
\text { drained } \\
\end{array}$ & Slight $3 \%$ & $\begin{array}{l}\text { Sandy } \\
\text { loam }\end{array}$ & $\begin{array}{c}\text { Moderately } \\
\text { shallow }(50-75 \\
\mathrm{cm})\end{array}$ \\
\hline Bichia (M.P) & Basalt & Undulating & $1-3$ & $\begin{array}{c}\text { Well } \\
\text { drained }\end{array}$ & Slight $3 \%$ & Clay loam & $\begin{array}{c}\text { Moderately } \\
\text { shallow (50-75 } \\
\mathrm{cm}) \\
\end{array}$ \\
\hline Niwas (M.P) & Basalt & Undulating & $3-5$ & $\begin{array}{c}\text { Well } \\
\text { drained }\end{array}$ & $\begin{array}{c}\text { Slight } 3-5 \\
\%\end{array}$ & $\begin{array}{l}\text { Gravelly } \\
\text { clay loam }\end{array}$ & $\begin{array}{l}\text { Moderately deep } \\
(75-100 \mathrm{~cm})\end{array}$ \\
\hline Balaghat (M.P) & $\begin{array}{l}\text { Granite, } \\
\text { gneiss } \\
\text { quartzite } \\
\text { schist } \\
\end{array}$ & Plain & $1-3$ & $\begin{array}{l}\text { Moderately } \\
\text { well } \\
\text { drained }\end{array}$ & Slight $3 \%$ & $\begin{array}{l}\text { Loamy } \\
\text { sand }\end{array}$ & $\begin{array}{l}\text { Moderately deep } \\
(75-100 \mathrm{~cm})\end{array}$ \\
\hline Khandwa (M.P.) & Basalt & Plain & $1-3$ & $\begin{array}{c}\text { Well } \\
\text { drained }\end{array}$ & $\begin{array}{c}\text { Slight } 3-5 \\
\%\end{array}$ & $\begin{array}{l}\text { Gravelly } \\
\text { sandy clay }\end{array}$ & $\begin{array}{l}\text { Shallow with } \\
\text { murrum after } 50 \\
\mathrm{~cm}(25-50 \mathrm{~cm})\end{array}$ \\
\hline Burhanpur (M.P.) & Basalt & Plain & $1-3$ & $\begin{array}{c}\text { Well } \\
\text { drained }\end{array}$ & Slight $3 \%$ & $\begin{array}{l}\text { Gravelly } \\
\text { clay loam }\end{array}$ & $\begin{array}{c}\text { Moderately } \\
\text { shallow }(50-75 \\
\mathrm{cm}) \\
\end{array}$ \\
\hline Nasik (Mahrashtra) & Basalt & Undulating & $>5$ & $\begin{array}{l}\text { Well } \\
\text { drained }\end{array}$ & $\begin{array}{l}\text { Moderate } \\
5-10 \%\end{array}$ & $\begin{array}{l}\text { Gravelly } \\
\text { loam }\end{array}$ & $\begin{array}{l}\text { Very shallow (10- } \\
25 \mathrm{~cm})\end{array}$ \\
\hline Chhindwara (M.P.) & Basalt & Plain & $1-3$ & $\begin{array}{c}\text { Well } \\
\text { drained }\end{array}$ & Slight $3 \%$ & $\begin{array}{l}\text { Sandy } \\
\text { loam }\end{array}$ & $\begin{array}{l}\text { Moderately deep } \\
(57-100 \mathrm{~cm})\end{array}$ \\
\hline Kundam (M.P.) & Basalt & Undulating & $3-5$ & $\begin{array}{c}\text { Well } \\
\text { drained }\end{array}$ & $\begin{array}{c}\text { Slight } 3-5 \\
\%\end{array}$ & $\begin{array}{c}\text { Gravelly } \\
\text { sandy } \\
\text { loam }\end{array}$ & $\begin{array}{c}\text { Moderately } \\
\text { shallow }(75-90 \\
\mathrm{cm})\end{array}$ \\
\hline Jabalpur (M.P.) & Basalt & Undulating & $3-5$ & $\begin{array}{c}\text { Well } \\
\text { drained }\end{array}$ & $\begin{array}{c}\text { Slight 3-5 } \\
\%\end{array}$ & Clay loam & $\begin{array}{c}\text { Shallow }(25-50 \\
\mathrm{cm})\end{array}$ \\
\hline
\end{tabular}

Jabalpur (S10), Gondia (S1) and Balaghat (S4), soil texture is mostly clay loam, sandy loam and loamy sand respectively.

Seed sources of J. curcas varied significantly in respect of seed weight and oil content in whole seed and in kernel (Table 3 ). The whole seed weight was highest in case of S8, which is at par with S2, S3 and S9. In case of weight of seed coat and kernel, the highest mean values were also found in S8 source and were at par with S2, S3, S9 and S7. The coefficient of variation for weight of whole seed, weight of seed coat and weight of kernel were found to be $10.25,6.15$ and 13.18 per cent respectively. Data revealed that the oil percentage of whole seed was highest in S8 source followed by S9 and S2 but these were also at par with each other. The oil contents of these three seed sources were found significantly higher than those from remaining seed sources. The least value for oil content in all seed sources was obtained in case of S5, which is also at par with S4. The oil yield obtained from kernels of S8 source

Table 3. - Source variation in seed weight and oil content of J. curcas.

\begin{tabular}{|l|l|l|l|l|l|}
\hline $\begin{array}{l}\text { Seed source } \\
\text { code }\end{array}$ & $\begin{array}{l}\text { Seed } \\
\text { weight (g.) }\end{array}$ & $\begin{array}{l}\text { Seed coat } \\
\text { (g.) }\end{array}$ & $\begin{array}{l}\text { Kernel } \\
\text { weight (g.) }\end{array}$ & $\begin{array}{l}\text { Oil content } \\
\text { in whole } \\
\text { seed (\%) }\end{array}$ & $\begin{array}{l}\text { Oil content } \\
\text { in kernel } \\
(\%)\end{array}$ \\
\hline S1 & 3.183 & 1.190 & 1.993 & 34.41 & 47.10 \\
S2 & 3.857 & 1.340 & 2.517 & 38.42 & 49.72 \\
S3 & 2.953 & 1.136 & 1.817 & 33.50 & 46.22 \\
S4 & 3.802 & 1.343 & 2.477 & 36.70 & 49.00 \\
S5 & 3.297 & 1.292 & 2.005 & 33.02 & 47.78 \\
S6 & 3.390 & 1.243 & 2.147 & 35.54 & 47.08 \\
S7 & 3.643 & 1.293 & 2.350 & 36.82 & 48.49 \\
S8 & 3.913 & 1.378 & 2.539 & 39.12 & 58.12 \\
S9 & 3.787 & 1.374 & 2.409 & 38.42 & 51.98 \\
S10 & 3.057 & 1.271 & 1.786 & 36.78 & 50.42 \\
& & & & & \\
\hline CV (\%) & 10.25 & 6.150 & 13.180 & 5.84 & 6.98 \\
C.D. (5\%) & 0.237 & 0.092 & 0.251 & 2.31 & 2.94 \\
SE \pm & 0.114 & 0.044 & 0.121 & 1.10 & 1.40 \\
\hline
\end{tabular}

$\mathrm{CD}=$ critical difference, $\mathrm{SE}=$ standard error of mean. exceeded significantly from all other seed sources. The least value for oil content from kernel was found in S4. The coefficient of variation for the oil content of whole seed and kernel was found to be 5.84 and 6.98 per cent respectively.

The seedlings raised from seeds collected from ten sources were evaluated for growth and survival at age 12 and 24 months of field planting. The corresponding mean performance values have been presented in Table 4. The height growth after one year of planting was registered higher in S8 followed by S9, S2 and S3, which were statistically at par with each other. The lowest value was recorded in S1 followed by S4 and S6. Collar diameter was recorded maximum in S8 followed by S9 and S3 and are statistically at par. Maximum number of branches were found in S7 source followed by S3, S2, S9, S8, S4, S6, S1 and S10. These sources were statistically at par in respect of number of branches. The field survival was recorded highest in S8, S9 and S10 sources and the lowest in S1, however no significant difference between the sources for this character was observed. The coefficient of variation for height, collar diameter, number of branches and field survival was found to be $9.17,7.88$ and 10.37 per cent respectively.

After 24 months of field planting, significant differences $(\mathrm{P}<0.05)$ were noticed among seed sources in height, collar diameter, number of branches, leaf area and survival per cent. The growth followed a more or less similar trend as was observed at age 12 months. A clear-cut distinction in the performance of the seed sources was observed at this age in which the S8 source out ranked the remaining ones with regard to height $(205.5 \mathrm{~cm})$, collar diameter $(41.95 \mathrm{~mm})$ and field survival $(88.89 \%)$. Numbers of branches were found maximum in S4 followed by S2, S8 and S3 and were statistically at par with each other. The survival percent was recorded highest in three sources viz. S8, S9 and S10. However the lowest survival was however recorded in $\mathrm{S} 1$. The average leaf area ranged between 
Table 4. - Growth performance of various seed sources after field planting.

\begin{tabular}{|c|c|c|c|c|c|c|c|c|c|c|}
\hline Seed source & \multicolumn{9}{|c|}{$\mathbf{1 2}$ month } & \multicolumn{4}{|c|}{$\mathbf{2 4}$ month } \\
\cline { 2 - 12 } & $\begin{array}{c}\text { Height } \\
(\mathrm{cm})\end{array}$ & $\begin{array}{c}\text { Collar } \\
\text { diameter } \\
(\mathrm{mm})\end{array}$ & $\begin{array}{c}\text { No. of } \\
\text { branches }\end{array}$ & $\begin{array}{c}\text { Field } \\
\text { survival } \\
(\%)\end{array}$ & $\begin{array}{c}\text { Height } \\
(\mathrm{cm})\end{array}$ & $\begin{array}{c}\text { Collar } \\
\text { diameter } \\
(\mathrm{mm})\end{array}$ & $\begin{array}{c}\text { No. of } \\
\text { branches }\end{array}$ & $\begin{array}{c}\text { Area of } \\
\text { single } \\
\text { leaf } \\
\left(\mathrm{cm}^{2}\right)\end{array}$ & $\begin{array}{c}\text { Total leaf } \\
\text { area } \\
\left(\mathrm{cm}^{2} / \mathrm{plant}\right)\end{array}$ & $\begin{array}{c}\text { Field } \\
\text { survival } \\
(\%)\end{array}$ \\
\hline S1 & 76.20 & 28.26 & 2.28 & 77.78 & 169.6 & 34.01 & 2.49 & 110.2 & 3679.58 & 69.45 \\
\hline S2 & 95.37 & 33.95 & 2.66 & 86.11 & 190.9 & 41.78 & 4.21 & 124.8 & 5040.67 & 80.55 \\
\hline S3 & 78.35 & 29.94 & 2.58 & 83.33 & 174.2 & 35.50 & 4.26 & 114.0 & 3904.50 & 72.22 \\
\hline S4 & 94.89 & 34.18 & 2.70 & 88.89 & 188.9 & 40.68 & 3.68 & 122.4 & 4937.62 & 86.11 \\
\hline S5 & 91.21 & 30.20 & 1.98 & 83.33 & 184.7 & 37.67 & 2.70 & 113.0 & 4156.14 & 77.78 \\
\hline S6 & 84.74 & 29.23 & 2.35 & 80.55 & 179.9 & 36.68 & 2.34 & 113.8 & 3989.81 & 80.55 \\
\hline S7 & 88.15 & 31.24 & 2.73 & 86.11 & 185.4 & 38.68 & 3.05 & 121.4 & 4782.53 & 80.55 \\
\hline S8 & 101.50 & 35.59 & 2.63 & 94.45 & 205.5 & 41.95 & 4.19 & 124.0 & 5272.48 & 88.89 \\
\hline S9 & 97.51 & 34.27 & 2.64 & 94.45 & 193.5 & 40.89 & 3.46 & 124.2 & 5038.46 & 88.89 \\
\hline S10 & 87.05 & 31.27 & 2.19 & 94.45 & 181.0 & 38.65 & 3.03 & 121.6 & 4421.38 & 88.89 \\
\hline CV (\%) & 9.17 & 7.88 & 10.37 & 6.73 & 5.51 & 7.01 & 21.79 & 4.65 & 12.46 & 8.52 \\
CD (5\%) & 8.75 & 1.62 & 0.59 & NS & 3.04 & 2.44 & 0.76 & 1.48 & 165.73 & 9.23 \\
SE \pm & 4.16 & 0.77 & 0.28 & - & 1.45 & 1.16 & 0.36 & 0.70 & 78.88 \\
\hline
\end{tabular}

NS - non significant. $\mathrm{CD}=$ critical difference, $\mathrm{SE}=$ standard error of mean.

$110.2 \mathrm{~cm}^{2}$ and $124.8 \mathrm{~cm}^{2}$. The maximum of which was found in S2 followed in S9 and S8 and the minimum in S1. The total leaf area per plant was recorded maximum in S8 source and S1 depicted the minimum. The coefficient of variation for height, collar diameter, number of branches, leaf area, total leaf area per plant and field survival was found to be 5.51, 7.01, 21.79 $4.65,12.46$ and 8.52 per cent respectively.

\section{Correlations}

The correlation coefficients ( $r$ ) among the seed, oil and growth traits are presented in Table 5. Whole seed weight was found to have higher significant positive relationship with seed kernel weight, seed oil content, kernel oil content, height (12 month and 24 months field growth), collar diameter (12 month and 24 months field growth), number of branches (12 month growth). Seed kernel weight was also correlated significantly with seed oil content, height and collar diameter of 12 and 24 month field growth, number of branches (12 month) and total leaf area (24 month). Similarly seed oil content and kernel oil content was found to have significant positive relationship with all the growth traits except the number of branches. Growth traits viz. height, collar diameter, leaf area and field survival were found to have significant inter-correlation with each other.

\section{Genetic analysis}

Variance components for growth traits are presented in Table 6 . There were fair differences between the values of genotypic and phenotypic variance and genotypic and phenotypic co-efficient of variation for all the characters. Wide range of variation was observed for each of the character studied. Estimates of broad sense heritabilities for growth traits were high and

Table 5. - Correlation coefficient ( $\mathrm{r}$ ) among the various traits.

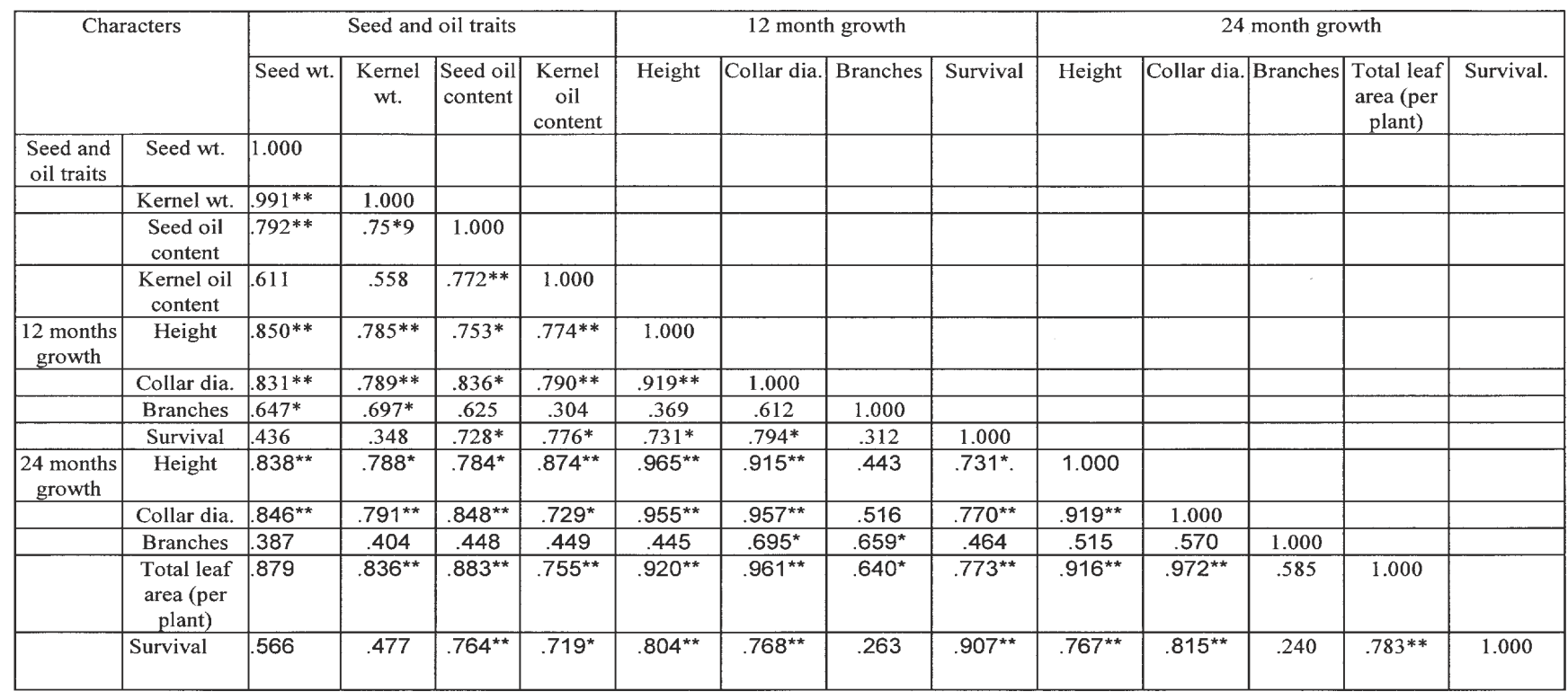

** Significant at the 0.01 level (2-tailed).

* Significant at the 0.05 level (2-tailed). 
Table 6. - Variability estimates in J. curcas for growth characteristics.

\begin{tabular}{|c|c|c|c|c|c|c|c|c|c|c|}
\hline \multirow{2}{*}{ Characters } & \multirow{2}{*}{ Range } & \multicolumn{3}{|c|}{ Variance } & \multicolumn{3}{|c|}{ Co-efficient of variability } & \multirow[t]{2}{*}{ Heritability } & \multirow{2}{*}{$\begin{array}{l}\text { Genetic } \\
\text { advance }\end{array}$} & \multirow{2}{*}{$\begin{array}{l}\text { Genetic } \\
\text { gain }\end{array}$} \\
\hline & & Phenotypic & Genotypic & \begin{tabular}{|l}
$\begin{array}{l}\text { Environ- } \\
\text { mental }\end{array}$ \\
\end{tabular} & Phenotypic & Genotypic & \begin{tabular}{|l}
$\begin{array}{l}\text { Environ- } \\
\text { mental }\end{array}$ \\
\end{tabular} & & & \\
\hline \multicolumn{11}{|l|}{12 months } \\
\hline Height & \begin{tabular}{|l|}
$76.20-$ \\
101.50 \\
\end{tabular} & 84.76 & 58.75 & 26.00 & 10.28 & 8.56 & 5.69 & 69.32 & 13.14 & 14.68 \\
\hline Collar diameter & \begin{tabular}{|l|}
$28.26-$ \\
35.59 \\
\end{tabular} & 6.87 & 5.98 & 0.89 & 8.24 & 7.69 & 2.97 & 87.00 & 4.70 & 14.77 \\
\hline Survival & \begin{tabular}{|l|}
$77.78-$ \\
94.45 \\
\end{tabular} & 63.67 & 24.82 & 38.84 & 9.17 & 5.73 & 7.16 & 38.99 & 6.41 & 7.37 \\
\hline \multicolumn{11}{|l|}{24 months } \\
\hline Height & $\begin{array}{l}169.6- \\
205.5\end{array}$ & 106.37 & 103.22 & 3.14 & 5.56 & 5.48 & 0.95 & 97.04 & 05.56 & 17.17 \\
\hline Collar diameter & \begin{tabular}{|l|}
$34.01-$ \\
41.95 \\
\end{tabular} & 8.70 & 6.67 & 2.02 & 7.63 & 6.68 & 3.68 & 76.68 & 04.66 & 12.06 \\
\hline Survival & $\begin{array}{l}69.45- \\
88.89 \\
\end{array}$ & 67.64 & 38.32 & 29.32 & 10.10 & 7.60 & 6.65 & 56.65 & 09.59 & 11.79 \\
\hline Single leaf area & \begin{tabular}{|l|}
$110.2-$ \\
124.8 \\
\end{tabular} & 31.11 & 30.33 & 0.74 & 4.691 & 4.63 & 0.72 & 94.49 & 11.20 & 09.42 \\
\hline $\begin{array}{l}\text { Total leaf area } \\
\text { (per plant) }\end{array}$ & $\begin{array}{l}3680- \\
5272 \\
\end{array}$ & 3790.78 & 28574.10 & 9333.700 & 43.07 & 37.39 & 21.37 & 75.38 & 302.33 & 66.88 \\
\hline
\end{tabular}

ranged from 38.99 to $97.04 \%$. The heritability values were lower for survival. The heritability for height was quite good and was 69.32 and $97.04 \%$ after one and two years field growth respectively. The values of heritability changed with the age with same set of genotypes. The genetic advance and genetic gains were worked out to be 5.56 and 17.17 respectively for height; 4.66 and 12.06 for diameter; 9.59 and 11.79 for survival; and 11.20 and 9.42 for leaf area at two years field growth. Genetic gains were recorded high for height, and collar diameter at both the age interval.

\section{Discussion}

J. curcas is being explored for its oil yield potential throughout the world. Attempts are therefore aimed at screening out J. curcas seed sources, which can produce better oil yield. Its kernel is found to contain 45-60 per cent oil (JONES and MiLLER, 1991). In the present study the oil yield was comparable to this reports. The populations of this species collected from the central region of India vary in their growing habitat in respect of altitude, temperature, soil conditions and rainfall. The sources used under this study had mean annual rainfall range from $714 \mathrm{~mm}$ to $1490 \mathrm{~mm}$. Also the source varied considerably in respect to site and soil conditions viz. slope, soil depth and soil

Table 7. - Gradation of sources based on weighted oil content.

\begin{tabular}{|l|l|l|l|}
\hline Seed source & $\begin{array}{l}\text { Oil content in seed } \\
\text { kernel (\%) }\end{array}$ & $\begin{array}{l}\text { Gradation } \\
\text { (considering } \\
\text { Chhindwara source } \\
\text { as 100) }\end{array}$ & $\begin{array}{l}\text { Difference between } \\
\text { two adjacent grades }\end{array}$ \\
\hline Chhindwara & 58.12 & 100.00 & - \\
Kundam & 51.98 & 89.43 & 10.57 \\
Jabalpur & 50.42 & 86.75 & 2.68 \\
Bichhia & 49.72 & 85.54 & 1.21 \\
Niwas & 49.00 & 84.30 & 1.24 \\
Nasik & 48.49 & 83.43 & 0.87 \\
Khandwa & 47.78 & 82.20 & 1.23 \\
Gondia & 47.10 & 81.03 & 1.17 \\
Burhanpur & 47.08 & 81.00 & 0.03 \\
Balaghat & 46.22 & 79.52 & 1.48 \\
\hline & & & Difference between \\
& & & maximum and \\
minimum 20.48
\end{tabular}

texture. Variation in sources of J. curcas with respect to growth performance is mainly due to the fact that this species grows over a wide range of rainfall, temperature and soil types in central India. Populations might have experienced marked differences in selective pressure.

The Chhindwara (M.P.) source was found far superior than the remaining nine sources. If the oil percentage of this source is taken for granted as 100 grades, the Kubdam (M.P.) source stands at 90 (Table 7). Accordingly oil grades of Jabalpur (M.P.), Bichia (M.P.) and Niwas (M.P.) seed sources would be equated to 85. Even Nasik (Maharashtra) seed source can be categorized fairly good performers. Other seed sources can be put in a group having low grades. Thus on the basis of oil yield seed sources under study can be categorized in four categories viz. as excellent (100 grade), very good (90-99 grades), good (85-89 grades) and moderate (80-84 grades).

The location of Chhindwara (M.P) source is at fairly high altitude in comparison to others and is characterized with less rainfall and moderately high temperature. The area is characterized with summer dry conditions in comparison to other sources. A drier climate is supposed to improve the oil yield in J. curcas seeds (JONES and MilleR, 1991). Also it is worth to mention here that the Chhindwara locality has better soil depth as compared to the other sources. Soil conditions play significant role in causing variation in oil yield (SRIVASTAVA, 1999). Phosphorus has been found to be the main requirement for increase in oil yield in the case of castor beans growing in East Africa (DE Geus, 1973). The other good performers were Kundam, Jabalpur (local), Bichia and Niwas, which also maintained their superiority throughout the observation period. These sources fall within the geographical belt of dry deciduous forests and are located within the range of $400 \mathrm{~km}$.

The seed sources in most of the cases were significantly different in oil yield and growth variables and have showed a considerable amount of genetic variability with in the distribution range indicating a good scope of genetic gain through selection. $J$. curcas is found mostly in India as small, discrete populations, which are the basic resources for future improvement 
and breeding programmes. The apparent variability in oil content along with variability in growth performance indicates that economic benefits may be obtained. The extent of variation in seed weight and oil content in the whole seed and kernel is large as compared to other traits. The consideration of seed weight in selecting and understanding the geographical variation has been advocated because of the least plasticity in this character (HRAPER et al., 1970). The results of the present study will be valuable for seed zone delineations, strategies for conservation of genetic variation, prospects of improvement and assessment of the potential of locally adapted seed source.

The patterns of variation (based on coefficient of variation) exhibited for various characters were substantially different and varied with age. The presence of such difference among populations has probably been produced by different intensities of natural selection acting upon these traits in their natural habitat. Some of the variation found, may be associated with the discrete populations from which seed was collected. Coefficient of variation for number of branches after two years of plantation is maximum (21.79 per cent). This attributes to differences in dimensions of form of tree crown (JANKIEWICZ and STECKI, 1976).

The local seed source in the present study ranked comparatively low in comparison to the highest oil and growth producing source i.e. Chhindwara. It is indicative that there is a better choice of using selected promising genotypes and populations from the range of distribution. Germplasm used in afforestation programmes in India and other countries, generally uses only the locally available material. By doing so, good opportunities might have been missed for using material with higher yield potential or with more desirable characteristics.

Tree breeding strategy is largely dependent upon the extent of variability in the base population which is measured by different parameters viz. genotypic and phenotypic variances, and genotypic and phenotypic co-efficient of variation (SUBRAMANIAN et al., 1995). The genotypic coefficients of variation are comparatively lower than phenotypic coefficient of variation for all the traits. RATHINAM et al. (1982) also reported similar results for height and girth, and SUBRAMANIAN et al. (1995) for height, girth and clear bole length. The estimates of broad sense heritabilities for growth traits indicate that a considerable portion of variance is additive. High additive genetic variance and large variation between seed sources offer good scope for genetic improvement of this species. Heritability in broad sense may also give useful indication about the relative value of selection of the material at hand, but to arrive at a more reliable conclusion, heritability and genetic advance may be considered jointly (SUBRAMANIAN et al., 1995). As expected the height and collar diameter registered higher values of genetic gain in comparison to other characters.

The phenotypic correlations among many seed and growth traits (Table 4) showed highly significant correlations. It is interesting to note that none of the character had shown negative correlation with each other, thus concluded that these characters may be used to the advantage of the breeder for bringing simultaneous improvement of these traits easily. The inter correlations found among seed weight and seedling characters in J. curcas are consistent with those of earlier studies (PAlmberg, 1975; IKTUERen, 1977; IsIK, 1986). Heavier seed have more oil and have better seedling growth in the field. The correlation suggests that following the completion of germination, seedling allocate much of their energies for root and shoot development. ASLAN (1975) had a detailed study on the relationship between seed dimensions and seedling quality in Pinus brutia. His results also indicated that larger and heavier seeds produced better quality of seedlings. Such relationship can be exploited for screening of genotypes to have an early indication on their oil yield and growth performance.

The present study shows that there exists considerable amount of genetic variability in this species in central India with respect to oil quantity and growth performance which offers scope to breeder for selection and breeding. It is quite clear that Chhindwara (M.P) source is good in growth performance particularly in the prevailing conditions in Jabalpur (M.P.). Also this source can yield maximum oil from seeds. The Kundam, Jabalpur (local), Bichia and Niwas sources also performed satisfactorily in respect to growth and oil yield. These sources can safely be used for large-scale reforestation programmes in this region for better oil yield and vegetative growth. The work further gives a direction to effect and practise studies for genetic improvement of this species. Perhaps, this is a first attempt and report, which surveys and quantifies oil percentage and assesses growth performance of J. curcas populations from central India.

\section{Acknowledgement}

The authors are grateful to the Director, Tropical Forest Research Institute, Jabalpur (M.P.) India, for providing necessary facilities for conducting the experiments.

\section{References}

ANONYMUS (1965): Official method of analysis $10^{\text {th }}$ edition, Association of Official Agricultural Chemists, Washington, D.C.

AsLAN, S. (1975): Relationship between seed dimensions and seedling percentage and seedling quality in Pinus brutia. Orm. Aras. Enst. Tek. Bult. No. 64, 39 pp. (in Turkish-English Summary).

BAKER, J. G. (1877): Flora of Maritises and seydselles. L. Recve \& Co., London, 1877: 322.

BAL KRISHNAN and ToKY, O. P. (1995): Provenance variation in growth characteristics of Acacia nilotica ssp. indica in arid India. Indian Forester 121 (3): 179-186.

Bhasabatra, R. and SutiponPeibun, S. (1982a): Jatropha curcas oil as a substitute for diesel engine oil. Renewable Energy Review Journal 4: 56-70.

Bhasabatra, R. and Sutiponpeibun, S. (1982b): The study of Jatropha curcas oil as a substitute of diesel engine oil. Thai. Verglon. Department of Agriculture, Ministry of Agriculture and Cooperatives, Bangkok, $42 \mathrm{pp}$.

De Geus, Jan G. (1973): Fertilizer Guide for the Tropics and Subtropics, Centre d' Etude de I' Azote, Bleicherweg 33, Zurich.

Harper, J. L., Lovell, P. H. and Moore, K. G. (1970): The shape and size of seeds. Annu. Rev. Ecol. Spet. 1: 327-356.

Heller, JoAchim (1996): Physic nut. Jatropha curcas L. Promoting the conservation and use of underutilized and neglected crops. 1. Institute of Plant Genetics and Crop Plant Research, Gatersleben/ International Plant Genetic Resources Institute, Rome.

Iktueren, S. (1977): Provenance experiments on Pinus brutia and Pinus pinea in Turkey. I : Seed and nursery results. Proc. TUBITAK VI. Sci. Congress. Agr. and For. Sect. Pp: 11-19, Ankara.

IsIK, K. (1986): Altitudinal variation in Pinus brutia Ten.: Seed and seedling characteristics. Silvae Genetica 35, 2-3.

IsTA. (1976): International rules for seed testing. Proc. Int. Seed Testing Assoc. 31: 1-152.

JANKIEWICZ, L. S. and STECKI, Z. J. (1976): Some mechanisms responsible for differences in tree forms. M.G.R. Cannel and F.T. Last (ed.). Tree physiology and yield improvement. Academic press, London, pp. 157-172.

JARRAY, S. (1984): Potential of physic nut (Jatropha curcas Linn.) as an energy source in Thailand. Agric. Res. Thailand 2(1): 67-72. 
JONES, N. and MiLleR, J. H. (1991): Jatropha curcas, a multipurpose species for problematic sites. Land Resource Series No. 1. The World Bank Asia Technical Department, Agriculture Division.

KempthoRne, O. (1957): An Introduction to Genetic Statistics. John Willey and Sons Lt., New York: 101-146.

MARTin, G. and MAYEZIX, A. (1984): Reflection on oil crops as source of energy II. The physic nut (Jatropha curcas L.): A possible source of fuel. Leagineux 39 (5): 283-287.

Munch, E. and KeIFER, J. (1989): Physic nut: a multipurpose plant as a future source of motor fuel. Zusammenarbeit 209 232.

PALMBerg, C. (1975): Geographic variation and early growth in southeastern semi-arid Australia of Pinus halepensis MiLL. and the Pinus brutia Ten. Species Complex. Silvae Genetica 24 (5-6): 150-159.

RAINA, A. K. (1985): Jatropha curcas fence against energy crisis. In: Proc. Bio-energy Society First Conv. \& Symposium. R. N. Sharma et al. (eds.). Bioenergy Society of India, New Delhi, 114-117.

Rathinam, M., Suerndran, C. and Kondas, S. (1982): Interrelationship of wood yield component in Eucalyptus tereticornis Sm. Indian Forester 108: 460-470.
Snedecor, G. W. and Cochran, W .G. (1967): Statistical Methods. Oxford and IBH, New Delhi. 593 pp.

SRIVASTAVA, R. (1999): Study in variation in morpho-physiological parameters with reference to oil yield and quality in Jatropha curcas Linn. Ph. D. thesis, Forest Research Institute (Deemed University), Dehradun, India.

Stewart, G. A., Rawlin, W. H. M., Quick, G. C., BeGG, J. E. and PEACOCK, W. J. (1981): Oil seeds as a renewable source of diesel fuel. Search 12: 107.

Subramanian, K. N., Mandal, A. K. and Nicodemus, A. (1995): Genetic variability and character association in Eucalyptus grandis. Annals of Forestry 3 (2): 134-137.

SuKARIN, W., YAMAdA, Y. and SAKAGUCHI, S. (1987): Characteristics of physic nut, Jatropha curcas L. as a new biomass crop in the Tropics. Jpn. Agric. Res. Quart. (Japan) 20(4): 302-303.

TAKEDA, Y. (1982b): Development study on Jatropha curcas (sabundan) oil as a substitute for diesel engine oil in Thailand. J. Agri. Assoc. 120: 1-8.

TAKEDA, Y. and MinORU, O. (1981): Interim report on the study of Jatropha curcas oil as a substitute for diesel engine oil. Industrial Finance Corporation, Thailand, Bangkok, Oct., 14.

\section{Buchbesprechung}

Transgene Pflanzen. Herstellung, Anwendung, Risiken und Richtlinien. Zweite, überarbeitete und aktualisierte Auflage. Peter Brandt. 2004. Public Relations, Birkhäuser Verlag AG, Basel, Berlin, Boston. ISBN 3-7643-5753-3. 376 Seiten. EUR 36,45 (Nettopreis, abhängig von der lokalen MwSt).

Nach der ersten Auflage des Erfolgsbuchs von Autor PETER BRANDT aus dem Jahr 1995 hat der Autor mit der vorliegenden zweiten Auflage der rasanten Entwicklung Rechnung getragen, die die Bio- und Gentechnologie in den letzten 15 Jahren gemacht hat. Kamen derartige Methoden zunächst nur in den Laboratorien von Forschungsinstitutionen zur Anwendung, haben sie heute längst Einzug in die Praxis der Züchtung landwirtschaftlicher Kulturpflanzen, der Herstellung von Lebensmitteln in der Lebensmittelindustrie und der Erzeugung lebenswichtiger Inhaltsstoffe von Medikamenten gefunden. Die Nutzung der Gentechnik wird zudem für die Therapie unheilbarer Krankheiten sowie für diagnostische Zwecke diskutiert. Gleichermaßen mit dem potentiellen Nutzen der neuen Technologie sind Rufe zu möglichen Risiken laut geworden. Befürchtungen über unkontrollierbare Folgen haben zur Verunsicherung in weiten Teilen der Bevölkerung geführt. So sehen viele Kritiker der Gentechnik noch unvorhersehbare bzw. noch unbekannte Risikopotentiale, obwohl der Gesetzgeber mit strengen Verfahrensregelungen Vorsorge für alle nur denkbaren Risiken geleistet hat. Ähnlich deszendiert wie in der ersten Auflage führt PETER BRANDT auch in diesem Buch in sachlicher und didaktisch überzeugender Weise in die brisante Thematik der transgenen Pflanzen ein. Zunächst werden Begriffe beschrieben, die im Zusammenhang mit transgenen Pflanzen wichtig sind, und Verfahren vorgestellt, wie der Transfer fremder Erbsubstanz in das Erbgut der Empfängerpflanzen gelingen kann. In den anschließenden zwei Kapiteln werden Kriterien, wie die genetische Stabilität der übertragenen Genkonstrukte sowie das „Abschalten“ von Genen, diskutiert. Nach einem kurzen Exkurs in die vergleichende Betrachtung der konventionellen Pflanzenzüchtung versus „Grüne Gentechnik“ gibt der Autor einen umfassenden Überblick über die erzeugten transgenen Pflanzen, denen Resistenzgene gegen z.B. Herbizide, Viren, Bakterien, Pilze übertragen wurden („Input-Traits“). Aber auch die Veränderung pflanzlicher Inhaltsstoffe oder Entwicklungsprozesse werden genauso berücksichtigt wie die Synthese pflanzenfremder Antikörper oder anderer Peptide („Output-Traits“). Besonders positiv ist zu werten, dass sich der Autor im letzten Teil des Buches sowohl mit dem Versuch einer Risikobewertung und dem Risikomanagement auseinandersetzt als auch den Vollzug gesetzlicher Regelungen für das beabsichtigte Freisetzen oder das Inverkehrbringen transgener Pflanzen beschreibt. Zusammengefasst ist das Buch jedem Interessierten zu empfehlen, der fachlich fundierte und ideologisch neutrale Informationen über den Stand der Gentechnik bei Pflanzen sucht.

gez. M. FLADUNG

Herausgeberin: Bundesforschungsanstalt für Forst- und Holzwirtschaft: Schriftleitung: Institut für Forstgenetik und Forstpflanzenzüchtung, Siekerlandstrasse 2, D-22927 Grosshansdorf — Verlag: J. D. Sauerländer's Verlag, Finkenhofstrasse 21, D-60322 Frankfurt a. M. Anzeigenverwaltung: J. D. Sauerländer's Verlag, Frankfurt am Main. Satz: Satz- und Grafikstudio König, Marburg — Druck: Druckerei Wenzel, Marburg — Printed in Germany. 